\title{
Lidia Anna Wiśniewska, Kobiece ciało - kobieca psychika. Ja- -cielesne a psychospołeczne funkcjonowanie mtodych kobiet, Wydawnictwo Naukowe UMK, Toruń 2014, ss. 305
}

Problem cielesności i jej doświadczania przez młode kobiety podjęty w publikacji Lidii Anny Wiśniewskiej nabiera w ostatnich latach szczególnego znaczenia. Wciąż wzrasta liczba osób niezadowolonych ze swojego ciała i decydujących się na różnorodne, nie zawsze zdrowe próby jego ulepszania. Poza coraz bardziej aktualnym problemem otyłości, nieustannie zwiększa się odsetek młodych kobiet rozpoczynających proces odchudzania, niezależnie od ich obiektywnej wagi.

W strukturze książki pt. Kobiece ciało - kobieca psychika. Ja-cielesne a psychospołeczne funkcjonowanie młodych kobiet można wyróżnić dwie części: teoretyczną i empiryczną. Na część teoretyczną składają się trzy rozdziały. W pierwszym z nich, opisującym problematykę cielesności z perspektywy psychologicznej, Autorka dokonała klaryfikacji głównego pojęcia oraz zidentyfikowała czynniki determinujące cielesność. Wśród zmiennych, które mają znaczący wpływ na jej kształtowanie i późniejszą percepcję, wyróżniła: czynniki fizyczne, związane z obiektywnymi wskaźnikami, takimi jak waga i wzrost; czynniki kulturowe, obejmujące m.in. mass media, oraz czynniki społeczne, związane z rolą rodziców, rówieśników i innych ludzi. W rozdziale drugim scharakteryzowano okres adolescencji z uwzględnieniem wybranych zmian rozwojowych w sferze biologicznej, psychicznej i społecznej. Natomiast rozdział trzeci poświęcony został ukazaniu znaczenia cielesności dla psychospołecznego funkcjonowania człowieka.

Głównym celem badawczym nakreślonym w części empirycznej było poznanie specyfiki psychospołecznego funkcjonowania młodych kobiet różniących się doświadczaniem własnej cielesności, a także poszukiwanie zależności między Ja-cielesnym i innymi zmiennymi osobowymi zidentyfikowanymi jako potencjalne zmienne istotne. Badania przeprowadzo- 
ne na grupie 183 młodych kobiet pokazały, że pozytywne doświadczanie własnej cielesności koreluje z niższym poziomem neurotyczności, wyższym poziomem ekstrawertyczności, sumienności i ugodowości. Analizy ujawniły ponadto, że młode kobiety z wyższym poziomem kompetencji interpersonalnych i empatii przeżywają własną cielesność w bardziej pozytywny sposób. Pozytywne doświadczanie własnej cielesności współwystępuje także z wysokim poziomem samooceny, poczucia jakości życia i akceptacji własnej wagi.

Skutkiem dalszych analiz empirycznych było wyodrębnienie wśród badanych kobiet trzech grup - różniących się doświadczaniem własnej cielesności. Pierwszą grupę ( $\mathrm{N}=93)$ - kobiet akceptujących swoją cielesność (silne Ja-cielesne) - charakteryzuje niski poziom depresyjności, dobre umiejętności panowania nad sobą, zrównoważenie emocjonalne, wysoki spokój wewnętrzny i poczucie bezpieczeństwa, wysokie kompetencje interpersonalne, serdeczność i przeżywanie emocji pozytywnych w relacjach $\mathrm{z}$ innymi. $\mathrm{W}$ drugiej grupie $(\mathrm{N}=53)$ znalazły się kobiety o niesprecyzowanym stosunku do własnej cielesności, które zachowując w życiu optymizm, przejawiają jednocześnie dość dużą łatwości wpadania w gniew i przeżywania frustracji. Trzecią grupę ( $\mathrm{N}=37)$ stanowią kobiety odrzucające własną cielesność, które ze względu na niski poziom akceptacji własnego ciała doświadczają trudności w bliskich relacjach, w tym w relacjach intymnych. Cechuje je ponadto słaba znajomość własnych stanów wewnętrznych, jak również podwyższony poziom depresyjności i lęku oraz trudności w kontrolowaniu własnych emocji.

Wyniki odnoszące się do zachowań prozdrowotnych ujawniły z kolei, iż stosunkowo dużo badanych kobiet podejmowało próby redukcji wagi, jednak niewiele z nich korzystało z pomocy specjalisty. Popularnymi sposobami, stosowanymi przez około połowę z odchudzających się kobiet, okazały się takie zachowania jak ograniczanie ilości spożywanych pokarmów oraz uprawianie sportu. Dał się zaobserwować równocześnie dość niebezpieczny trend, jakim jest sięganie po środki farmakologiczne dostępne bez recepty.

Podsumowując, o walorach recenzowanej książki stanowią głównie: aktualność i istotność podjętej problematyki, interesująca treść prezentowanego tekstu oraz jego wyraźny aspekt aplikacyjny, szczególnie w badaniach nad stałością i złożonością Ja-cielesnego. Na uwagę zasługuje również praktyczny wymiar uzyskanych wyników badania. Można je wykorzystać m.in. w pracy lekarzy rodzinnych, którzy nie tylko mogą nakłaniać młode kobiety do dbania o swoje zdrowie, ale również udzielać im 
wsparcia przy podejmowanych próbach odchudzania. I wreszcie fakt, iż silne Ja-cielesne może stanowić barierę zabezpieczającą przed zachowaniami ryzykownymi związanymi z ulepszaniem swojego ciała (rygorystyczne diety, nadmierne ćwiczenia fizyczne), może być wykorzystany podczas organizowanych dla młodych kobiet warsztatów, mających na celu kształtowanie ich kompetencji społecznych.

Agata Wołowska 